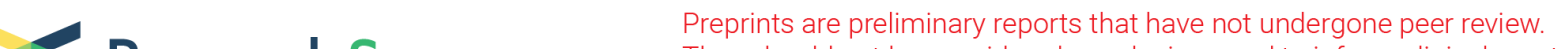 Research Square They should not be considered conclusive, used to inform clinical practice, or referenced by the media as validated information.
}

\section{Active constituents of Zanthoxylum nitidium from Yunnan Province against leukaemia cells in vitro}

\section{Ying Deng}

College of Pharmacy, Guizhou University

\section{Tongtong Ding}

Key laboratory of chemistry for natural products of GuizhouProvince and Chinese Academy of Sciences

\section{Lulu Deng}

State Key Laboratory of Function and Applications of Medicinal Plants

\section{Xiaojiang Hao}

State Key Labotratory of Functions and Applications of Medicinal Plants

Shu Zhen Mu (D muzi0558@126.com )

College of Pharmacy, Guizhou University

\section{Research article}

Keywords: Zanthoxylum nitidium, alkaloids, benzophenanthrene, leukaemia, HEL cell, cell cycle, cell apoptosis

Posted Date: November 13th, 2020

DOI: https://doi.org/10.21203/rs.2.22293/v5

License: (c) (1) This work is licensed under a Creative Commons Attribution 4.0 International License. Read Full License

Version of Record: A version of this preprint was published at BMC Chemistry on July 23rd, 2021. See the published version at https://doi.org/10.1186/s13065-021-00771-0. 


\section{Abstract}

Zanthoxylum nitidium (Roxb.) DC (Rutaceae) is well known for inhibiting the proliferation of human gastric, liver, kidney and lung cancer cells, though research on its potential use in treating leukaemia is relatively rare. Twenty-six compounds were isolated from the chloroform and petroleum ether extracts of the roots and leaves of $Z$. nitidium. They were (+)-9'-O-transferuloyl-5, 5'-dimethoxylaricriresinol (1), 8-(3'oxobut-1'-en-1'-yl)-5, 7-dimethoxy-coumarin (2), 5, 7, 8-trimethoxy-coumarin (3), 5-(3', 3'-dimethyl-2'butenyloxy)-7, 8-dimethoxy-coumarin (4), 2-(5-methoxy-2-methyl-1 H-indol-3-yl) methyl acetate (5), 2'-(5, 6dihydrochleletrythrine-6-yl) ethyl acetate (6), 6-acetonyldi-hydrochelerythrine (7), $6 \beta$ hydroxymethyldihydronitidine (8), bocconoline (9), zanthoxyline (10), $O$-methylzanthoxyline (11), rhoifoline B (12), N-nornitidine (13), nitidine (14), chelerythrine (15), 4-hydroxyl-7,8-dimethoxyfuroquinoline (16), dictamnine (17), $\gamma$-fagarine (18), skimmianine (19), robustine (20), R-(+)-platydesmine (21), 4-methoxyl-1-methyl-2-quinoline (22), 4-methoxy-2-quinolone (23), liriodenine (24), aurantiamide acetate (25), 10-O-demethyl-12-O-methylarnottianamide (26). Four among them, compounds 4-6 and 16, were first confirmed in this study by UV, IR, 1D, 2D NMR and HR-ESI-MS spectra. Compounds 1-2 and 11 were isolated from $Z$. nitidium for the first time. Of the assayed compounds, 1, 2, 9, 10, 14, 15 and 24, exhibited good inhibitory activities in the leukaemia cell line $\mathrm{HEL}$, whereas compound $14\left(\mathrm{IC}_{50}: 3.59 \mu \mathrm{M}\right)$ and compound $24\left(\mathrm{IC}_{50}: 15.95 \mu \mathrm{M}\right)$ exhibited potent inhibitory activities. So, to further investigate the possible mechanisms, cell cycle and apoptosis assays were performed, which indicated that compound $\mathbf{1 4}$ causes obvious S-phase arrest in HEL cells and induced apoptosis, whereas compound $\mathbf{2 4}$ only induced apoptosis. The present results suggested both compounds 14 and 24 are promising potential anti-leukaemia drug candidates.

\section{Introduction}

Leukaemia is closely related to the haematopoietic system, which includes the bone marrow [1], and malignant tumours of the haematopoietic system pose a serious threat to human health and life. Although early high-dose combination chemotherapies can achieve complete remission in many patients, the 5-year survival rate of these patients is still unsatisfactory [2], and the discovery of new antileukaemia drugs is very important.

Identifying candidate drug molecules in natural products is an important approach for discovering innovative drugs. Zanthoxy/um nitidium (Roxb.) DC, locally called "liangmianzhen", belongs to the family Rutaceae [3]. The palnt is distributed in Guangdong, Fujian, Yunnan, and Taiwan provinces of China. The chemical components of $Z$. nitidium are diverse and complex, including alkaloids, flavonoids, lignans and coumarins. Research on active substances has mainly focused on alkaloids, especially benzophenanthridine, furanquinoline, quinolones, amides, and aporphine, and a much smaller number of non-alkaloids have also been reported [4]. To data, previous studies on the biological activity of $Z$. nitidium have examined inhibition of the proliferation of human gastric, liver, kidney, lung and nasopharyngeal carcinoma cells [5]. In contrast, the anti-leukaemia properties of this plant are comparatively unknown. High expression of Fli-1 gene plays an important regulatory role in the 
process of vascular endothelial cell generation and tumour cell proliferation, as well as in promoting tumorigenesis and development [6, 7]. As the Fli- 1 gene is a new target for drug screening, we sought to investigate the involvement of inhibitory effects on Fli-1 against leukaemia by active compounds of $Z$. nitidium.

In our previous work, ethanol extracts of $Z$. nitidium exhibited significant inhibitory effects on the proliferation of HEL cells, which highly express Fli-1, with no significant toxicity in vitro. To find a lead compound with a good effect on the Fli-1 gene, 26 compounds were isolated, purified and identified from the roots and leaves of $Z$. nitidium from Yunnan province, and their antitumour activities against HEL cells were evaluated. The chemical structures of compounds 4, 5, $\mathbf{6}$ and 16 were first characterized through spectroscopic analyses based on UV, IR, 1D and 2D NMR, and HR-ESI-MS spectra. Moreover, the antitumor activities of the 26 compounds in HEL cells were first evaluated, and the possible mechanism of two active compounds was investigated.

\section{Materials And Methods}

\section{Chemical reagents}

INOVA-600 MHz superconducting nuclear magnetic resonance spectrometer (American Varian, TMS internal standard); HPMS5973 mass spectrometer (HP, USA); ZF-2 type three-purpose UV instrument (Shanghai Anting Electronic Instrument Factory); silica gel G (Qingdao Ocean Chemical Plant Branch) and reversed-phase silica gel C-18 (Rp-18, 40-63 m) (Amersham Biosciences, Sweden) for column chromatography; silica gel plates GF254 (Qingdao Puke Separation Material Co., Ltd.) for thin-layer chromatography; Sephadex LH-20 (Amersham Biosciences, Sweden); deuterated reagents for NMR spectroscopy (Wuhan Spectrum Company of Chinese Academy of Sciences); $5 \%(\varphi)$ concentrated sulfuric acid ethanol solution, an $8 \%(\omega)$ phosphomolybdic acid ethanol solution, and a modified caesium iodide potassium test solution for staining TLC plates; $3111 \mathrm{CO}_{2}$ incubator (Thermo Fisher Scientific Co., Ltd.); X-15R centrifuge (Backman, USA); Synergy2 multi-function microplate detector (Gene Branch Chengdu Branch); TS100 Nikon binocular inverted microscope (Shanghai Shisen Vision Technology Co., Ltd.); BD AccuriTM C6 flow cytometer (BD Biosciences); 96-well culture plates (Nisi Biotechnology Co., Ltd.); and 6-well culture plates (Nisi Biotechnology Co., Ltd.).

\section{Biological reagents}

Human leukaemia cell line HEL (ATCC); adriamycin (Solarbio, D8740); Dulbecco's modified Eagle medium (DMEM, Gibco, C11995500CP); foetal bovine serum (Bio IND, 04-002-1A); antibiotic-antimycotic (Life Technologies, 15240-112); bovine serum albumin (Life Technologies, 15561012); Cell Titer Glo (CTG, PROMEGA, G7572); flow cytometer (ACEN, NovoCyte); microplate reader (BioTek, EPOCH); annexin V and propidium iodide (PI, DOJINDO, AD10).

\section{Plant material}


The roots and leaves of Zanthoxylum nitidum (Roxb.) DC. were collected in Mengla County, Xishuangbanna, Yunnan Province. The plant material was identified as Zanthoxylum nitidium (Roxb.) DC. by Dr. Chunfang Xiao, Xishuangbanna Tropical Botanical Garden, Chinese Academy of Sciences.

\section{Extraction and isolation}

Air-dried roots and leaves of $Z$. nitidum $(20.0 \mathrm{~kg})$ were extracted by refluxing in $95 \% \mathrm{EtOH}(100 \mathrm{~L})$ three times $(4,3$, and $2 \mathrm{~h})$. After filtration, the combined EtOH extracts were concentrated to remove the alcohol, and the residue was resuspended in an appropriate volume of water. The mixture was extracted three times with equal volumes of petroleum ether and chloroform to afford $180.0 \mathrm{~g}$ of petroleum ether extract and $190.2 \mathrm{~g}$ of chloroform extract. The chloroform extract $(190.2 \mathrm{~g})$ was separated on a silica gel $(50-74 \mu \mathrm{m})$ column eluted with a gradient of chloroform-MeOH (volume ratio: 100冈 1 to $0 \otimes 100$ ) to obtain 15 fractions (Fr.1 Fr.15). The Fr.2 fraction was recrystallized from the chloroform-MeOH solvent to afford compound $10(1.3 \mathrm{~g})$; Fr.4 was recrystallized to afford compound $24(360 \mathrm{mg})$. Each fraction was repeatedly subjected to normal-phase silica gel column chromatography, reversed-phase silica gel column chromatography and Sephadex LH-20 column chromatography (alternating the use of $\mathrm{MeOH}$ and chloroform-MeOH as the eluents) to afford compounds 1 (15 mg), 2 (49 mg), 3 (20 mg), 4 (90 mg), 5 (19 mg), 6 (5 mg), 7 (50 mg), 8 (11 mg), 9 (29 $\mathrm{mg}), 11$ (22 mg), 12 (30 mg), 13 (6 mg), 14 (58 mg), 15 (7 mg), 16 (30 mg), 20 (14 mg), 21 (5 mg), 23 (22 $\mathrm{mg}), 25(8 \mathrm{mg})$, and $26(20 \mathrm{mg})$. The petroleum ether extract $(180.0 \mathrm{~g})$ was separated on a silica gel (50$74 \mu \mathrm{m}$ ) column eluted with a gradient of petroleum ether-ethyl acetate (volume ratio: 100: 1 to 0: 100) to afford 8 fractions. The same purification method was used to obtain compounds 17 (30 mg), 18 (460 $\mathrm{mg}), 19$ (60 mg), and 22 (31 mg).

\section{5-(3',3'-dimethyl-2'-butenyloxy)-6,8-dimethoxy-coumarin (4)}

Yellow solid. UV $\left(\mathrm{CH}_{3} \mathrm{OH}\right) \lambda$ max: 206, 263 and $323 \mathrm{~nm} .{ }^{1} \mathrm{H}$ and ${ }^{13} \mathrm{C}$ NMR (Table 1). HR-ESI-MS: $\mathrm{m} / \mathrm{z}$ $313.1585[\mathrm{M}+\mathrm{Na}]^{+}$(calculated for $\mathrm{C}_{16} \mathrm{H}_{18} \mathrm{O}_{5}$ ).

\section{2-(5-methoxy-2-methyl-1H-indol-3-yl) methyl acetate (5)}

Tawny oil. UV $\left(\mathrm{CH}_{3} \mathrm{OH}\right) \lambda$ max: 218 and $279 \mathrm{~nm} .{ }^{1} \mathrm{H}$ and ${ }^{13} \mathrm{C}$ NMR (Table 2). HR-ESI-MS: $m / z$ 234.1124 $[\mathrm{M}+\mathrm{H}]^{+}$(calculated for $\mathrm{C}_{13} \mathrm{H}_{15} \mathrm{O}_{3} \mathrm{~N}$ ).

\section{2'-(5,6-dihydrochleletrythrine-6-yl) ethyl acetate (6)}

Yellow oil. UV ( $\left.\mathrm{CH}_{3} \mathrm{OH}\right) \lambda$ max: 201, 283 and $224 \mathrm{~nm} .{ }^{1} \mathrm{H}$ and ${ }^{13} \mathrm{C}$ NMR (Table 3). HR-ESI-MS: $\mathrm{m} / \mathrm{z}$ $436.1752[\mathrm{M}+\mathrm{H}]^{+}\left(\left(\right.\right.$calculated for $\left.\mathrm{C}_{14} \mathrm{H}_{13} \mathrm{O}_{4} \mathrm{~N}\right)$.

\section{4-hydroxyl-7,8-dimethoxy-furoquinoline (16)}


Tawny solid. UV $\left(\mathrm{CH}_{3} \mathrm{OH}\right) \lambda$ max: 249, 201 and $316 \mathrm{~nm} .{ }^{1} \mathrm{H}$ and ${ }^{13} \mathrm{C}$ NMR (Table 4). HR-ESI-MS: $\mathrm{m} / z$ 246.0760 [M+ H] $]^{+}$(calculated for $\mathrm{C}_{13} \mathrm{H}_{12} \mathrm{O}_{4} \mathrm{~N}$ ).

\section{CAS numbers}

5, 7, 8-trimethoxy-coumarin $(3,60796-65-8), 2$-(5-methoxy-2-methyl-1 $H$-indol-3-yl) methyl acetate $(\mathbf{5}, 7588$ 36-5), 6-acetonyldi-hydrochelerythrine (7, 15575-49-2), bocconoline (9, 112025-60-2), zanthoxyline (10, 54354-62-0), O-methylzanthoxyline (11, 6900-99-8), nitidine (14, 13063-04-2), chelerythrine (15, 34316-159), dictamnine (17, 484-29-7), $y$-fagarine (18, 524-15-2), skimmianine (19, 83-98-4), robustine $(20,2255-$ 50-7), R-(+)-platydesmine (21, 7764-73-0), 4-methoxy-2-quinolone (23, 27667-34-1), liriodenine (24, 47575-2), aurantiamide acetate $(25,56121-42-7)$, and 10-O-demethyl-12-O-methylarnottianamide (26, 1234313-87-1).

\section{CTG assay for antitumour activity}

The human leukaemia cell line HEL was purchased from American Type Culture Collection, and the cells were cultured in DMEM. All media were supplemented with 10\% foetal bovine serum (FBS), 100 units $/ \mathrm{mL}$ penicillin, and 100 units $/ \mathrm{mL}$ streptomycin (Invitrogen). The cells were cultured at $37^{\circ} \mathrm{C}$ in a humidified environment with $5 \% \mathrm{CO}_{2}$ and passaged once every 2 days for three generations. The cells were incubated in fresh cell culture medium and washed carefully to avoid false-positive results. Briefly, HEL cells $\left(8 \times 10^{3}\right.$ cells per well) were seeded into 96 -well plates, and the plates were incubated for $24 \mathrm{~h}$. Then, $10 \mu \mathrm{L}$ of adriamycin were added as a positive control, and $10 \mu \mathrm{L}$ of various concentrations $(40,20,10,5$, $2.5,1.25 \mu \mathrm{M})$ of compounds $\left(5 \times 10^{-6} \mathrm{~mol} / \mathrm{L}\right)$ were added as the test group, with 5 wells per group. After incubation for $72 \mathrm{~h}, 20 \mu \mathrm{L}$ of CTG reagent were added, and the cells were incubated for $10 \mathrm{~min}$. After centrifugation (1500 rpm, $15 \mathrm{~min}$ ) the supernatant was poured off, $160 \mu \mathrm{L}$ of DMSO were added to each well, and the plate was heated and shaken for $10 \mathrm{~min}$. Finally, the chemiluminescence of each well were determined using a microplate reader. After the experiment were repeated three times, the $\mathrm{IC}_{50}$ value were calculated from the curves generated by plotting the percentage of viable cells versus the tested concentration on a logarithmic scale using Sigma Plot 10.0 software.

\section{Cell apoptosis analysis}

Apoptosis was detected by flow cytometry using Annexin V-FITC according to the manufacturer's protocol (BD Biosciences). HEL cells were treated with compounds 14 and 24 for $36 \mathrm{~h}$ before Annexin $\mathrm{V}$ and propidium iodide staining. The cells were kept under dark conditions at room temperature for $15 \mathrm{~min}$ before being subjected to flow cytometry analysis.

\section{Cell cycle analysis}


Cell cycle analysis was conducted by propidium iodide (PI) staining after treatment with compounds 14 and 24 for $36 \mathrm{~h}$. Briefly, cells were plated in culture dishes and cultured with prepared DMEM medium for $12 \mathrm{~h}$, after which the cells were treated with compounds $\mathbf{1 4}$ and $\mathbf{2 4}$ for $36 \mathrm{~h}$, and the supernatant was removed. The treated cells were fixed with $70 \%$ ethanol overnight before staining with PI mixed with RNase. The cells were kept under dark conditions at room temperature for $30 \mathrm{~min}$ before being subjected to flow cytometry analysis.

\section{Statistical analysis}

All measurements were made in triplicate, and all data are expressed as the means \pm SEM of three independent experiments. Significant differences from the respective control for each experimental group were examined by one-way analysis of variance (ANOVA) using GraphPad Prism 5 software. $P<0.05$ was considered statistically significant.

\section{Results And Discussion}

\section{Isolation and structural elucidation}

Dried roots and leaves $(20 \mathrm{~kg})$ of $Z$. nitidium were heated and refluxed in $95 \% \mathrm{EtOH}$. The resulting extract was concentrated and then partitioned between petroleum ether and chloroform. The extracts were further separated by recrystallization and various forms of column chromatography (CC) to afford compounds 1-26 (Figure 1).

\section{$<$ Figure $1>$}

\section{Chemical structure of compound 4}

Compound 4 was obtained as yellow solid with a molecular formula of $\mathrm{C}_{16} \mathrm{H}_{18} \mathrm{O}_{5}$ deduced from its HRESI-MS spectrum $\left(\mathrm{m} / \mathrm{z} 291.1585[\mathrm{M}+\mathrm{H}]^{+}\right)$. The UV profile of 4 displayed the $\lambda$ max values of 206,263 and $323 \mathrm{~nm}$, and its IR spectrum showed absorptions representing a lactone ring $\left(1726 \mathrm{~cm}^{-1}\right)$ and an aromatic ring (1502 and $1432 \mathrm{~cm}^{-1}$ ). The above data indicated that compound 4 contains a lactone ring. The ${ }^{1} \mathrm{H}$-NMR data (Table 1$)$ showed the following: three aromatic proton signals $\left[\delta_{\mathrm{H}} 7.96(\mathrm{~d}, J\right.$ $=7.1 \mathrm{~Hz}, 1 \mathrm{H}), 6.16(\mathrm{~d}, J=7.1 \mathrm{~Hz}, 1 \mathrm{H})$, and $6.33(\mathrm{~d}, J=1.5 \mathrm{~Hz}, 1 \mathrm{H})]$; two methoxyl moieties $\left[\delta_{\mathrm{H}} 3.94(\mathrm{~s}, 3 \mathrm{H})\right.$ and $3.90(\mathrm{~s}, 3 \mathrm{H})]$; two methyl $\left[\delta_{\mathrm{H}} 1.68(\mathrm{~s}, 3 \mathrm{H})\right.$ and $\left.1.73(\mathrm{~s}, 3 \mathrm{H})\right]$; and one methylene $\left[\delta_{\mathrm{H}} 4.54(\mathrm{dd}, J=7.5,1.5\right.$ $\mathrm{Hz}, 2 \mathrm{H})]$. The above nuclear magnetic resonance data are similar to those reported for compound 4 ' in the literature [8-9].

\section{$<$ Table $1>$}

A previous report [8] suggested the carbon signals of the C-8 and C-5 of compound 4 ' were slightly distinct with compound 4 . Therefore, we speculate that the different carbon chemical shift at C-8 and C-5 may be caused by 3', 3'-dimethyl-2'-butenyloxy group positions. As illustrated in Figure 2, HMBC 
correlations of the protons $\mathrm{H}-1^{\prime}\left(\delta_{\mathrm{H}} 4.54\right)$ with $\mathrm{C}-2^{\prime}\left(\delta_{\mathrm{C}} 120.2\right), \mathrm{C}-3^{\prime}\left(\delta_{\mathrm{C}} 139.0\right)$, and $\mathrm{C}-5$ $\left(\delta_{\mathrm{C}} 128.8\right)$ indicated that the $3^{\prime}, 3^{\prime}$-dimethyl-2'-butenyloxy group of compound 4 is attached at the $\mathrm{C}$ 5 position. $\mathrm{HMBC}$ correlations of $\mathrm{H}-4\left(\delta_{\mathrm{H}} 7.96\right)$ to $\mathrm{C}-5 \mathrm{a}\left(\delta_{\mathrm{C}} 149.0\right), \mathrm{C}-2\left(\delta_{\mathrm{C}} 160.9\right)$ and $\mathrm{C}-5\left(\delta_{\mathrm{C}} 128.8\right) ; \mathrm{H}-3$ $\left(\delta_{\mathrm{H}} 6.16\right)$ to $\mathrm{C}-8 \mathrm{a}\left(\delta_{\mathrm{C}} 103.9\right)$ and $\mathrm{C}-2\left(\delta_{\mathrm{C}} 160.9\right)$ indicated that the lactone ring is close to $\mathrm{C}-8$. Finally, the proton chemical shift for $7-\mathrm{OCH}_{3}\left(\delta_{\mathrm{H}} 3.94, \mathrm{~s}\right)$, as based on $\mathrm{HMBC}$ data, correlates with the $\mathrm{C}-7$ $\left(\delta_{\mathrm{C}} 156.6\right)$, and the signal for $8-\mathrm{OCH}_{3}\left(\delta_{\mathrm{H}} 3.90, \mathrm{~s}\right)$ correlates with the $\mathrm{C}-8\left(\delta_{\mathrm{C}} 152.3\right)$. The two $-\mathrm{OCH}_{3}$ groups are at $\mathrm{C}-7$ and $\mathrm{C}-8$. The above nuclear magnetic resonance data indicated that compound $\mathbf{4}$ is consistent with 5-(3', 3'-dimethyl-2'-butenyloxy)-7, 8-methoxy-coumarin, which has been previously reported in the literature [10]. As the ${ }^{13} \mathrm{C}$-NMR data of compound $\mathbf{4}$ were not assigned in the literature, its 1D and 2D NMR data were analyzed in this study.

\section{$<$ Figure 2 >}

\section{Chemical structure of compound 5}

Compound $\mathbf{5}$ was isolated as a tawny oil. Its molecular formula was determined to be $\mathrm{C}_{13} \mathrm{H}_{15} \mathrm{O}_{3} \mathrm{~N}$ based on its positive HR-ESI-MS data $\left(\mathrm{m} / z\right.$ 234.1124 $\left.[\mathrm{M}+\mathrm{H}]^{+}\right)$. The UV profile of $\mathbf{5}$ displayed the $\lambda$ max values at 218 and $279 \mathrm{~nm}$, and the IR spectrum showed absorptions for an $\alpha, \beta$-unsaturated ester carbonyl (1731 $\mathrm{cm}^{-1}$ ) and an aromatic ring (1593 and $\left.1430 \mathrm{~cm}^{-1}\right)$. According to the ${ }^{1} \mathrm{H}-\mathrm{NMR}$ data in Table 2, there are three aromatic protons chemical shift $\left[\delta_{\mathrm{H}} 7.04(\mathrm{~m}, 1 \mathrm{H}), 6.75(\mathrm{dd}, J=8.7,2.4 \mathrm{~Hz}, 1 \mathrm{H})\right.$, and $6.98(\mathrm{~d}, J=8.7$ $\mathrm{Hz}, 1 \mathrm{H})]$, a methylene moiety $\left[\delta_{\mathrm{H}} 3.65(\mathrm{~s}, 2 \mathrm{H})\right]$, and two methoxy $\left[\delta_{\mathrm{H}} 3.84(\mathrm{~s}, 3 \mathrm{H})\right.$ and $\left.3.65(\mathrm{~s}, 3 \mathrm{H})\right]$. The above nuclear magnetic resonance data indicated that compound 5 is consistent with 2-(5-methoxy-2methyl-1 H-indol-3-yl) methyl acetate, which has been previously reported in the literature [11].

\section{$<$ Table $2>$}

Similar to compound $\mathbf{4}$, the ${ }^{13} \mathrm{C}-\mathrm{NMR}$ data for compound $\mathbf{5}$ was not reported in the previous literature, and the 1D and 2D NMR data were thus analysed. As depicted in Table 2, the coupling constant of the proton chemical shift at $\mathrm{H}-6\left(\delta_{\mathrm{H}} 6.75\right)$ and $\mathrm{H}-7\left(\delta_{\mathrm{H}} 6.98\right)$ is $J=8.7 \mathrm{~Hz}$, suggesting that the two proton signals are ortho-coupled to the benzene ring. The three protons at $\delta_{\mathrm{H}} 7.04(\mathrm{~m}, 1 \mathrm{H}), \delta_{\mathrm{H}} 6.75(\mathrm{dd}, J$ $=8.7,2.4 \mathrm{~Hz}, 1 \mathrm{H}), \delta_{\mathrm{H}} 6.98(\mathrm{~d}, J=8.7 \mathrm{~Hz}, 1 \mathrm{H})$ correlated with carbons at $\delta_{\mathrm{C}} 111.1,110.8$ and $100.4 \mathrm{in}$ HSQC spetrum, respectively, indicated an aromatic ring. At the same time, the HMBC data (Figure $3)$ showed correlations of $\mathrm{H}-8\left(\delta_{\mathrm{H}} 3.65\right)$ with $\mathrm{C}-2\left(\delta_{\mathrm{C}} 132.8\right), \mathrm{C}-3\left(\delta_{\mathrm{C}} 128.9\right)$, and $\mathrm{C}-4 \mathrm{a}\left(\delta_{\mathrm{C}} 104.1\right)$, suggesting that the compound contains an indole moiety; and of $\mathrm{H}-10\left(\delta_{\mathrm{H}} 2.28\right)$ with $\mathrm{C}-2\left(\delta_{\mathrm{C}} 132.8\right)$, suggesting the presencen of a methyl acetate. Finally, the HMBC data revealed a correlation of 5$\mathrm{OCH}_{3}\left(\delta_{\mathrm{H}} 3.84, \mathrm{~s}\right)$ with $\mathrm{C}-5\left(\delta_{\mathrm{C}} 154.1\right)$ and of $9-\mathrm{OCH}_{3}\left(\delta_{\mathrm{H}} 3.65, \mathrm{~s}\right)$ with $\mathrm{C}-9\left(\delta_{\mathrm{C}} 172.8\right)$. These results indicated that the two $-\mathrm{OCH}_{3}$ groups are at $\mathrm{C}-5$ and $\mathrm{C}-9$. Compound 5 was thus named 2-(5-methoxy-2methyl-1 H-indol-3-yl) methyl acetate.

\section{$<$ Figure $3>$}




\section{Chemical structure of compound 6}

Compound 6 was isolated as a yellow oil. Its molecular formula was determined to be $\mathrm{C}_{25} \mathrm{H}_{25} \mathrm{O}_{6} \mathrm{~N}$ based on its positive HR-ESI-MS data $\left(\mathrm{m} / \mathrm{z} 436.1752[\mathrm{M}+\mathrm{H}]^{+}\right)$. The UV profile of 6 revealed $\lambda$ max values of 201, 283 and $224 \mathrm{~nm}$ and its IR spectrum showed absorption bands for an $a, \beta$-unsaturated ester carbonyl $\left(1736 \mathrm{~cm}^{-1}\right)$ and an aromatic ring (1492 and $\left.1463 \mathrm{~cm}^{-1}\right)$. The ${ }^{1} \mathrm{H}-\mathrm{NMR}$ (Table 3 ) spectrum of compound 6 showed signals characteristic for two pairs of aromatic protons chemical shift $\left[\delta_{\mathrm{H}} 7.73(\mathrm{~d}\right.$, $J=8.7 \mathrm{~Hz}, 1 \mathrm{H})$ and $7.50(\mathrm{~d}, J=8.7 \mathrm{~Hz}, 1 \mathrm{H}), 6.99(\mathrm{~d}, J=8.5 \mathrm{~Hz}, 1 \mathrm{H})$ and $7.58(\mathrm{~d}, J=8.5 \mathrm{~Hz}, 1 \mathrm{H})$ ], two aromatic proton signals $\left[\delta_{\mathrm{H}} 7.57(\mathrm{~s}, 1 \mathrm{H})\right.$ and $\left.7.12(\mathrm{~s}, 1 \mathrm{H})\right]$, two groups of methyl $\left[\delta_{\mathrm{H}} 2.68(\mathrm{~s}, 3 \mathrm{H})\right.$ and 1.21 $(\mathrm{dd}, J=7.1 \mathrm{~Hz}, 3 \mathrm{H})]$, three methylene moieties $\left[\delta_{\mathrm{H}} 6.06(\mathrm{~s}, 2 \mathrm{H}), 2.38(\mathrm{~s}, 2 \mathrm{H})\right.$ and $4.17(\mathrm{~d}, J=7.1 \mathrm{~Hz}$, $2 \mathrm{H})]$, and two methoxy $\left[\delta_{\mathrm{H}} 3.99(\mathrm{~s}, 3 \mathrm{H})\right.$ and $\left.3.95(\mathrm{~s}, 3 \mathrm{H})\right]$. Compound 6 is a benzophenanthridine alkaloids based on the above nuclear magnetic resonance data. We found compound 6 to be consistent with 2'(5, 6-dihydrochleletrythrine-6-yl) ethyl acetate, which has been previously reported in the literature [12].

\section{$<$ Table 3 >}

The NMR data for compound $\mathbf{6}$ were assigned for the first time according to its 2D-NMR data. From the ${ }^{1} \mathrm{H}-\mathrm{NMR}$ data in Table 3 , the coupling constant between the proton signals at $\mathrm{H}-11\left(\delta_{\mathrm{H}} 7.73\right)$ and $\mathrm{H}-12$ $\left(\delta_{\mathrm{H}} 7.50\right)$ is $\mathrm{J}=8.7 \mathrm{~Hz}$, and that between $\mathrm{H}-9\left(\delta_{\mathrm{H}} 6.99\right)$ and $\mathrm{H}-10\left(\delta_{\mathrm{H}} 7.58\right)$ is $\mathrm{J}=8.5 \mathrm{~Hz}$, indicating that the two pairs of protons chemical shift are ortho-coupled to the phenyl ring. As depicted in Figure 4, HMBC data exhibited correlations of $\mathrm{H}-1\left(\delta_{\mathrm{H}} 7.12\right)$ with $\mathrm{C}-2\left(\delta_{\mathrm{C}} 148.0\right), \mathrm{C}-12\left(\delta_{\mathrm{C}} 124.0\right)$, and $\mathrm{C}-12 \mathrm{a}\left(\delta_{\mathrm{C}} 127.5\right)$ and of $\mathrm{H}-4\left(\delta_{\mathrm{H}} 7.57\right)$ with $\mathrm{C}-3\left(\delta_{\mathrm{C}} 147.5\right)$ and $\mathrm{C}-4 \mathrm{~b}\left(\delta_{\mathrm{C}} 139.3\right)$, indicating that compound 6 is a benzophenanthrene derivative. The direct HSQC (Figure S19, Supplementary Materials) correlations between $\mathrm{H}-6\left(\delta_{\mathrm{H}} 4.95\right)$ and $\mathrm{C}-6\left(\delta_{\mathrm{C}} 55.1\right)$ also demonstrated that compound 6 is a chelerythrine. Similarly, based on the HMBC (Figure 4), the correlations of $\mathrm{H}-2{ }^{\prime}\left(\delta_{\mathrm{H}} 2.38\right)$ with $\mathrm{C}-2\left(\delta_{\mathrm{C}} 148.0\right), \mathrm{C}-1{ }^{\prime}\left(\delta_{\mathrm{C}} 171.7\right)$, and C$6\left(\delta_{\mathrm{C}} 55.1\right)$ and of $\mathrm{H}-4^{\prime}\left(\delta_{\mathrm{H}} 1.21\right)$ with $\mathrm{C}-3^{\prime}\left(\delta_{\mathrm{C}} 60.3\right)$ suggested the presence of an ethyl acetate group. Finally, the $\mathrm{HMBC}$ correlations of $7-\mathrm{OCH}_{3}\left(\delta_{\mathrm{H}} 3.99\right)$ with $\mathrm{C}-7\left(\delta_{\mathrm{C}} 145.5\right)$ and of 8-0CH $\mathrm{CH}_{3}\left(\delta_{\mathrm{H}} 3.95\right)$ with $\mathrm{C}-8$ $\left(\delta_{\mathrm{C}} 152.1\right)$ indicated that the two $-\mathrm{OCH}_{3}$ groups are at $\mathrm{C}-7$ and $\mathrm{C}-8$.

\section{$<$ Figure $4>$}

\section{Chemical Structure of compound 16}

Compound 16 was obtained as tawny solid with a molecular formula of $\mathrm{C}_{13} \mathrm{H}_{11} \mathrm{O}_{4} \mathrm{~N}$ deduced from its HRESI-MS spectrum $\left(\mathrm{m} / \mathrm{z} 246.0760[\mathrm{M}+\mathrm{H}]^{+}\right)$. The UV profile of 16 revealed $\lambda$ max values of 249,201 and $316 \mathrm{~nm}$, which are similar to those of quinoline [11]. The IR spectrum displayed absorption bands for an aromatic ring (1516 and $1443 \mathrm{~cm}^{-1}$ ) and an ether (1151 and $\left.1046 \mathrm{~cm}^{-1}\right)$. As indicated in Table 4, ${ }^{1} \mathrm{H}-$ NMR detected two pairs of aromatic proton signals $\left[\delta_{\mathrm{H}} 8.13(\mathrm{~d}, J=9.1 \mathrm{~Hz}, 1 \mathrm{H})\right.$ and $7.54(\mathrm{~d}, J=9.1 \mathrm{~Hz}$, $1 \mathrm{H}), 7.15(\mathrm{~d}, J=2.7 \mathrm{~Hz}, 1 \mathrm{H})$ and $7.80(\mathrm{~d}, J=2.7 \mathrm{~Hz}, 1 \mathrm{H})$ ], two methoxy moieties $\left[\delta_{\mathrm{H}} 4.23(\mathrm{~s}, 3 \mathrm{H})\right.$ and 4.27 $(\mathrm{s}, 3 \mathrm{H})]$, and an active hydrogen chemical shift $\left[\delta_{\mathrm{H}} 12.03(\mathrm{~s}, 1 \mathrm{H})\right]$. Based on the above nuclear magnetic 
resonance data, compound 16 is consistent with 4-hydroxy-7, 8-dimethoxy-furoquinoline, which has been previously reported in the literature [14].

\section{$<$ Table 4 >}

To clarify the structure of 16 , we for the first time assigned its NMR data. The ${ }^{1} \mathrm{H}-\mathrm{NMR}$ data (Table 4), showed a coupling constant between the chemical shift at $\mathrm{H}-5\left(\delta_{\mathrm{H}} 8.13\right)$ and $\mathrm{H}-6\left(\delta_{\mathrm{H}} 7.54\right)$ is $J=9.1$ $\mathrm{Hz}$; these two proton signals are ortho-coupled to the phenyl ring. The HMBC data in Figure 5 illustrate the correlations of $\mathrm{H}-5\left(\delta_{\mathrm{H}} 8.13\right)$ with $\mathrm{C}-4\left(\delta_{\mathrm{C}} 142.3\right), \mathrm{C}-8\left(\delta_{\mathrm{C}} 151.6\right)$, and $\mathrm{C}-8 \mathrm{a}\left(\delta_{\mathrm{C}} 157.4\right)$ and of $\mathrm{H}-6\left(\delta_{\mathrm{H}} 7.54\right)$ with $\mathrm{C}-6\left(\delta_{\mathrm{C}} 117.3\right), \mathrm{C}-8\left(\delta_{\mathrm{C}} 151.6\right)$, and $\mathrm{C}-4 \mathrm{a}\left(\delta_{\mathrm{C}} 114.1\right)$, suggesting that compound 16 contains a quinoline ring. Similarly, the coupling constant between the chemical shift at $\mathrm{H}-3 \mathrm{~b}\left(\delta_{\mathrm{H}}\right.$ 7.15) and $\mathrm{H}-2 \mathrm{a}\left(\delta_{\mathrm{H}} 7.80\right)$ is $J=2.7 \mathrm{~Hz}$, indicating that the protons are ortho-coupled to a furan ring. According to the HMBC data in Figure 5 , correlations of $\mathrm{H}-3 \mathrm{~b}\left(\delta_{\mathrm{H}} 7.15\right)$ with $\mathrm{C}-2\left(\delta_{\mathrm{C}} 164.5\right), \mathrm{C}-3\left(\delta_{\mathrm{C}}\right.$ $101.6)$, and $\mathrm{C}-4\left(\delta_{\mathrm{C}} 142.3\right)$ and of $\mathrm{H}-2 \mathrm{a}\left(\delta_{\mathrm{H}} 7.80\right)$ with $\mathrm{C}-2\left(\delta_{\mathrm{C}} 164.5\right), \mathrm{C}-3\left(\delta_{\mathrm{C}} 101.6\right)$, and $\mathrm{C}-3 \mathrm{~b}\left(\delta_{\mathrm{C}} 105.3\right)$ suggest that this compound is a furan derivative. Finally, $\mathrm{HMBC}$ correlations of $7-\mathrm{OCH}_{3}\left(\delta_{\mathrm{H}} 4.23\right)$ with $\mathrm{C}-7$ $\left(\delta_{\mathrm{C}} 140.2\right)$ and of $8-\mathrm{OCH}_{3}\left(\delta_{\mathrm{H}} 4.27\right)$ with $\mathrm{C}-8\left(\delta_{\mathrm{C}} 151.6\right)$ were observed. These results indicated that the two $-\mathrm{OCH}_{3}$ groups are located at $\mathrm{C}-7$ and $\mathrm{C}-8$. The above nuclear magnetic resonance data showed that compound $\mathbf{1 6}$ is consistent with 4-hydroxy-7, 8-dimethoxy-furoquinoline, which has been previously reported in the literature [14], though no 1D and 2D NMR data were reported. Herein, its NMR data of compound 16 were also assigned in the present study.

\section{$<$ Figure $5>$}

Overall, twenty-two compounds (compounds 5-26) were found to be alkaloids; the other four (compounds 1-4) were considered to be false-positive non-alkaloids based on the modified potassium caesium iodide test, as proven based on ${ }^{1} \mathrm{H}-\mathrm{NMR}$ and ${ }^{13} \mathrm{C}$-NMR spectra. In addition, by the comparison of NMR data with those described in the literature, the 26 compounds were identified as (+)-9'-O-transferuloyl-5, 5'-

dimethoxylaricriresinol (1) [15], 8-(3'-oxobut-1'-en-1'-yl)-5, 7-dmethoxy-coumarin (2) [16], 5, 7, 8-trimethoxycoumarin (3) [14], 5-(3', 3'-dimethyl-2'-butenyloxy)-7, 8-dimethoxy-coumarin (4), 2-(5-methoxy-2-methyl-1 Hindol-3-yl) methyl acetate (5), 2'-(5, 6-dihydrochleletrythrine-6-yl) ethyl acetate (6), 6-acetonyldihydrochelerythrine (7) [18], 6ß-hydroxymethyldihydronitidine (8) [19], bocconoline (9) [20], zanthoxyline (10) [33], O-methylzanthoxyline (11) [21], rhoifoline B (12) [22], N-nornitidine (13) [23], nitidine (14) [24], chelerythrine (15) [25], 4-hydroxyl-7, 8-dimethoxy-furoquinoline (16), dictamnine (17) [26], $\gamma$-fagarine (18) [27], skimmianine (19) [13], robustine (20) [26], R-(+)-platydesmine (21) [28], 4-methoxyl-1-methyl-2quinoline (22) [27], 4-methoxy-2-quinolone (23) [29], liriodenine (24) [30], aurantiamide acetate (25) [31], and 10-O-demethyl-12-O-methylarnottianamide (26) [32].

\section{Biological activities of the isolated compounds}

To analyse the effects of the 26 compounds on leukaemia cells (HEL cell lines), their $\mathrm{IC}_{50}$ values against HEL cells proliferation were determined by the CTG method, using adriamycin $\left(\mathrm{IC}_{50}: 0.021 \mu \mathrm{M}\right)$ 
as a positive control. As presented in Table 5, compound $\mathbf{1 4}\left(\mathrm{IC}_{50}: 3.59 \mu \mathrm{M}\right)$ and compound $\mathbf{9}\left(\mathrm{IC}_{50}: 7.65\right.$ $\mu \mathrm{M})$ showed the most potent inhibitory activities against HEL cells, compounds $15\left(\mathrm{IC}_{50}: 15.52 \mu \mathrm{M}\right)$ and $24\left(\mathrm{IC}_{50}: 15.95 \mu \mathrm{M}\right)$ exhibited moderate inhibitory activities against $\mathrm{HEL}$ cells. As the structures of compound $\mathbf{1 4}$ and compound $\mathbf{2 4}$ differ, different compounds of Z. nitidium may have inhibitory activity in HEL cells.

\section{$<$ Table $5>$}

\section{Compounds 14 and 24 induced cell cycle arrest}

To confirm the effects of compounds $\mathbf{1 4}$ and $\mathbf{2 4}$ with different structures on the cell cycle, the cell cycle distribution of HEL cells was examined after treatment with the compounds for $36 \mathrm{~h}$. As illustrated in Figure 6, significant S-transition arrest was observed in HEL cells treated with compound 14, which provided the most significant effect. Indeed, the fraction of cells in the S-phase was dosedependently increased by treatment with 14 , and the population of cells in S-phase was markedly increased to $52.04 \%$ in cells treated with $8 \mu \mathrm{M}$ compared to $37.92 \%$ in untreated cells. Conversely, compound 24, with a different structure, had no obvious effect on the HEL cell cycle.

\section{$<$ Figure $6>$}

\section{Compounds 14 and 24 induced apoptosis of HEL cells}

To determine whether the antiproliferative activity of $\mathbf{1 4}$ and $\mathbf{2 4}$ is accompanied by enhanced leukaemia cell apoptosis, flow cytometry and an Annexin V-FITC apoptosis detection kit were used to detect apoptosis. Compared with untreated cells, cells treated with compounds $\mathbf{1 4}$ and $\mathbf{2 4}$ displayed significant dose-dependent increases, as shown in Figure 7. At the same time, compound $\mathbf{2 4}$ at $7.5 \mu \mathrm{M}$ and 15.0 $\mu \mathrm{M}$ induced significant increases in apoptosis compared with the control group (DMSO). Compound 24 at concentrations of $7.5,15$ and $30 \mu \mathrm{M}$ promoted apoptosis from $6.11 \%$ and $17.34 \%$ to $25.81 \%$ in a dosedependent manner. Hence, compounds $\mathbf{1 4}$ and $\mathbf{2 4}$ caused obvious apoptosis in HEL cells in a concentration-dependent manner.

\section{Conclusions}

In summary, four compounds (4-6 and 16) with incomplete spectra and 22 known compounds were isolated and identified from the chloroform and petroleum ether extracts of the roots and leaves of $Z$. nitidium. The chemical structures of compounds $\mathbf{4 - 6}$ and 16 were elucidated by thorough spectroscopic analyses, and compounds 1, 2 and $\mathbf{1 1}$ were isolated from $Z$. nitidium for the first time. Among the isolated compounds, $\mathbf{1}, \mathbf{2}, \mathbf{9}, \mathbf{1 0}, \mathbf{1 4}, 15$ and $\mathbf{2 4}$, which are alkaloids, exhibited good inhibitory activities in the leukaemia cell line $\mathrm{HEL}$, whereas compound $14\left(\mathrm{IC}_{50}: 3.59 \mu \mathrm{M}\right)$ and compound $24\left(\mathrm{IC}_{50}: 15.95 \mu \mathrm{M}\right)$ exhibited potent inhibitory activities. To clarify the effect of different compound structure $\mathbf{1 4}$ and $\mathbf{2 4}$ in HEL cells, apoptosis and cell cycle assays showed that compound $\mathbf{1 4}$ possesses antiproliferative activity, and induces S-phase cell cycle arrest and apoptosis in HEL cells. In contrast, compound $\mathbf{2 4}$ only induced 
apoptosis in HEL cells. These results indicated that benzophenanthridine alkaloids had significant inhibition activities in leukaemia cells, providing new ideas for the structural modification and

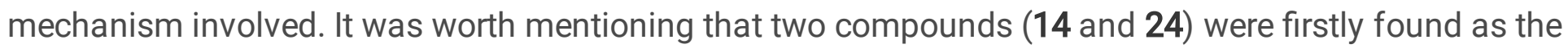
potential lead compounds with a good effect on the Fli-1 gene in leukaemia.

\section{Abbreviations}

${ }^{1} \mathrm{H}-\mathrm{NMR}$ : Proton nuclear magnetic resonance; ${ }^{13} \mathrm{C}$-NMR: Carbon: nuclear magnetic resonance; HMBC: Heteronuclear multiple bond correlation; HSQC: heteronuclear single quantum coherence; ${ }^{1} \mathrm{H}-{ }^{1} \mathrm{H}$ COSY: Homonuclear chemical shift Correlation Spectroscopy; DMSO: Deuterated dimethyl sulfoxide; HEL: The human erythroleukemia lines.

\section{Declarations}

\section{Consent for publication}

We consent for publication.

\section{Availability of data and material}

We have presented all our main data in the form of tables, figures and supplementary.

\section{Competing Interest}

The authors declare no conflicts of interest.

\section{Funding}

This work was financially supported by the National Natural Science Foundation of China (No. 31760097 and U1812403-3-3)

\section{Author Contributions}

D.Y. performed part of the chemical experiments and wrote the paper; M.S.Z. and H.X.J conceived of and designed the experiments and revised the paper; D.L.L. and D.T.T. performed the biological experiments and revised the paper.

\section{Author details}

${ }^{1}$ State Key Laboratory of Functions and Applications of Medicinal Plants, Guizhou Medical University, Guiyang 550014, China. ${ }^{2}$ College of Pharmacy, Guizhou University, Guiyang 550025, China. ${ }^{3}$ Key Laboratory of Chemistry for Natural Products of Guizhou Province and Chinese Academy of Sciences, Guiyang 550002, China. ${ }^{*}$ Correspondence: e-mail: muzi0558@126.com; Tel.: 13765801160 
Acknowledgements

The authors thank the National Natural Science Foundation of China.

\section{References}

1. Piller G (2001) Leukaemia-A brief historical review from ancient times to 1950. Brit J Haematol 112(2):282-292.

2. Cao ZC (2007) Comprehensive treatment and new progress of leukemia. J Mod Oncol 15(8):10511054.

3. Commission CP (2015) Pharmacopoeia of the People's Republic of China. China Medical Science Press: Beijing, China pp:169-170.

4. Wen P, Liu QT, Gao YL, Ma YM (2019) Research progress on the Zanthoxyli Radix. Strait Pharm J 31(01):30-31.

5. Huang Q, Lei P, OuYang DS (2011) Progress on anti-tumor effects of Zanthoxy/um nitidum (Roxb.) DC.. Anti-tumor Pharm 1(6):482-485.

6. Wang XM, Cui JK, Wang GJ (2011) The role of Fli-1 in tumorigenesis and development. J Jinlin Univ 003(037):567-570.

7. Paulette MF, Herrmann FR, Bshara W, Odunsi K, Luigi T, Guido S, Cheney, Jeff G, Remedios P, Paulette

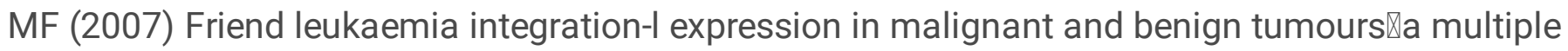

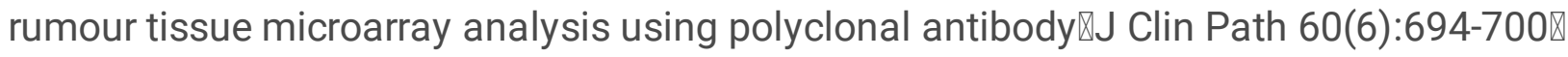

8. Szabo G, Greger H, Hofer O (1985) Coumarin-hemiterpene ethers from artemisia species. Phytochem 24(3):537-541.

9. Dominick M, Maria ER, Carina S, Carina S, Carlos D, Silvia D, Norbert DK (2008) Total synthesis of naturally occurring 5,6,7- and 5,7,8-trioxygenated coumarins. Tetrahedron 64(19):4438-4443.

10. Hofer O, Szabo G, Nikiforov A (1986) Leaf coumarins from the artemisia laciniata group. Liebigs Ann Chem 18(8):2142-2149.

11. Raji I, Yadudu F, Janeria E, Fathi S, Szymczak L, Kornacki JR, Komatsu K, Li JD, Mrksich M, Oyelere AK (2017) Bifunctional conjugates with potent inhibitory activity towards cyclooxygenase and histone deacetylase. Bioor Med Chem 25(3):1202-1218.

12. Liu ZY, Huang YJ, Xie HQ, Liu W (2016) A novel C-C radical-radical coupling reaction promoted by visible light: facile synthesis of 6-substituted: $\mathrm{N}$-methyl 5,6-dihydrobenzophenanthridine alkaloids. RSC Advances 6(56):50500-50505.

13. Fan J, Li HX, Wang BY, Hu W, Li HR (2013) Isolation, identification and activity determination on the anti-inflammatory components of roots of Zanthoxylum nitidum. J Shenyang Pharm Univ 30(6):5863.

14. Huang A, Xu H, Zhan R, Chen WW, Liu JW, Chi YG, Chen D, Ji XY, Luo CQ (2017) Metabolic profile of skimmianine in rats determined by ultra performance liquid chromatography coupled with 
quadrupole time-of-flight tandem mass spectrometry. Molecular 22(4):489.

15. Kwon HC, Choi SU, Lee JO, Bae KH, Lee KR (1999) Two new lignans from Lindera obtusiloba blume. Archi Pharm Res 22(4):417-422.

16. Kinoshita T, Wu J, Ho FC (2010) The isolation of a prenylcoumarin of chemotaxonomic significance from Murraya paniculata var. omphalocarpa. Phytochem 43(1):125-128.

17. Deshmukh MN, Deshpande VH, RamaRao AV (1976) Two new coumarins from Toddalia aculeate. Phytochem 15(9):1419-1420.

18. Wang CF, Fan L, Tian M, Du SS, Deng ZW, Feng JB, Wang YY, Su X (2015) Cytotoxicity of benzophenanthridine alkaloids from the roots of Zanthoxylum nitidum (Roxb.) DC. var. fastuosum How ex Huang. Nat Prod Res 29(14): 1380-1383.

19. Sheng XH, Mu SZ, Wang QY, Wang QY, Xie XD, Deng LL (2016) Isolation and identification of the chemical constituents from the roots of Zanthoxylum nitidum (Roxb.) DC.. J Shenyang Pharm Univ 33(4): $275-279+292$.

20. Ishii H, Ishikaka T, Hosoya K (1978) Studies on the chemical constituents of Rutaceous Benzo [c] phenanthridinium salt with methanol. Chem Pharm Bull 2(3):166-170.

21. Mouran NF, Ribeiro HB, Machado ECS, Machado EM, Ethur NZ, Ademir FM (1997) Benzophenanthridine alkaloids from Zanthoxylum rhoifolium. Phytochem 46(8):1443-1446.

22. Gonzaga WA, Weber AD, Giacomeli SR, Dalcol II, Hoelzel SCS, Morel AF (2003) Antibacterial alkaloids from Zanthoxylum Rhoifolium. Planta Med 69(4):371-374.

23. Jaromir T, Jiri D, Radek M (2004) Theoretical and experimental NMR chemical shifts of norsanguinarine and norchelerythrine. J Mol Struct 68:115-120.

24. Huang ZX, Li ZH (1980) Studies on the antitumor constituents of Zanthoxylum nitidum (Roxb.) DC.. J Chem 13(12):535-542.

25. Xu L, Niu SL, Wu ZL, Liu X, Shi F (2009) Study on the benzophenidine alkaloids in Zanthoxylum nitidum (Roxb.) DC.. Chin Tradit herbal Drug 40:538-540.

26. Liu QW, Tan CH, Qu SJ, Fan X, Zhu DY (2006) Chemical constituents of Evodia fargesii Chin J Nat Med 4(1):25-29.

27. Min YD, Kong HC, Yang MC, Lee KH, Choi SU, Lee KR (2007) Isolation of limonoids and alkaloids from phellodendron amurense and their multidrug resistance (MDR) teversal activity. Arch Pharm Res 30(1):58-63.

28. Pusset J, Lopez JL, Pais M, Neirabeyeh MA, Veillon JM (1991) Isolation and 2D NMR studies of alkaloids from comptonella sessilfoliola. Plan Med 57(2):153-155.

29. Raquel RG, Radwan MM, Burandt CL, Williamson JS, Ross SA (2010) Xenobiotic biotransformation of 4-methoxy-N-methyl-2-quinolone, isolated from Zanthoxylum monophyllum. Nat Prod Commun 5(9):1463-1467.

30. Li L, Zhang P, Liang D, Xiao W, Li X (2009) NMR characteriion of 7-oxo-aporphine alkaloids. Chin J Mag Res 26:400-407. 
31. Wang ZT, Lu YH, Ye WC, Xu LS, Xu GJ, Shu YZ (1999) A Dipeptide Isolated from Aster tataricus L.f. J Chin Pharm Sci (03)171-172.

32. Ngoumfo RM, Jouda JB, Mouafo FT, Komguem J, Mbazoa CD, Shiao TC, Choudhary MI, Laatsch H, Legault J, Pichette A, Roy R (2010) In vitro cytotoxic activity of isolated acridones alkaloids from Zanthoxylum leprieurii Perr. Bioor Medl Chem 18(10):3601-3605.

33. Deng Y, Sheng XH, Deng LL, Hao XJ, Mu SZ (2020) Study on the alkaloids and their anticancer activity from Zanthoxylum nitidium 32(08):1370-1378.

\section{Tables}

Table $1{ }^{1} \mathrm{H}(600 \mathrm{MHz})$ and ${ }^{13} \mathrm{C}(151 \mathrm{MHz})$ NMR data for compound 4 in $\mathrm{CDCl}_{3}$

\begin{tabular}{|c|c|c|c|}
\hline Position & $\delta_{\mathrm{H} \square \mathrm{m}} \mathrm{J} J$ in $\left.\mathrm{Hz}\right]$ & $\delta_{\mathrm{C}}$ & HMBC \\
\hline 2 & & 160.9 & \\
\hline 3 & $6.16, d,(7.1)$ & 111.0 & C-8a, C-2 \\
\hline 4 & $7.96, d,(7.1)$ & 138.8 & $C-5 a, C-2, C-5$ \\
\hline 5 & & 128.8 & \\
\hline 6 & $6.33, \mathrm{~d}(1.5)$ & 91.3 & C-8a, C-5, C-8, C-7 \\
\hline 7 & & 156.6 & \\
\hline 8 & & 152.3 & \\
\hline $8 a$ & & 103.9 & \\
\hline $5 a$ & & 149.0 & \\
\hline $1^{\prime}$ & $4.54, \mathrm{dd}(7.5,1.5)$ & 70.0 & $\mathrm{C}-2^{\prime}, \mathrm{C}-5, \mathrm{C}-3^{\prime}$ \\
\hline $2^{\prime}$ & $5.57, d(1.5)$ & 120.2 & $C-4^{\prime}, C-5^{\prime}$ \\
\hline $3^{\prime}$ & & 139.0 & \\
\hline $4^{\prime}$ & $1.68, \mathrm{~s}$ & 18.0 & $C-5^{\prime}, C-2^{\prime}, C-3^{\prime}$ \\
\hline $5^{\prime}$ & $1.73, \mathrm{~s}$ & 25.8 & $\mathrm{C}-4^{\prime}, \mathrm{C}-2^{\prime}, \mathrm{C}-3^{\prime}$ \\
\hline $7-\mathrm{OCH}_{3}$ & $3.94, \mathrm{~s}$ & 56.4 & $\mathrm{C}-7$ \\
\hline $8-\mathrm{OCH}_{3}$ & $3.90, \mathrm{~s}$ & 56.4 & $\mathrm{C}-8$ \\
\hline
\end{tabular}

Table $2{ }^{1} \mathrm{H}(600 \mathrm{MHz})$ and ${ }^{13} \mathrm{C}(151 \mathrm{MHz}) \mathrm{NMR}$ data for compound 5 in $\mathrm{CDCl}_{3}$.

\begin{tabular}{|c|c|c|c|}
\hline Position & $\delta_{\mathrm{H} \square} \mathrm{m} \rrbracket J$ in $\mathrm{Hz} \rrbracket$ & $\delta_{\mathrm{C}}$ & HMBC \\
\hline 2 & & 132.8 & \\
\hline 3 & & 128.9 & \\
\hline 4 & $7.04, \mathrm{~m}$ & 111.1 & $C-5, C-3, C-7$ \\
\hline 5 & & 154.1 & \\
\hline 6 & $6.75, \mathrm{dd}(8.7,2.4)$ & 110.8 & $C-7, C-5, C-7 a$ \\
\hline 7 & $6.98, \mathrm{~d}(8.7)$ & 100.4 & C-7a, C-5, C-6, C-4, C-4a \\
\hline $4 \mathbf{a}$ & & 104.1 & \\
\hline $7 a$ & & 130.2 & \\
\hline 8 & $3.65, \mathrm{~s}$ & 30.3 & $C-2, C-3, C-4 a$ \\
\hline 9 & & 172.8 & \\
\hline 10 & $2.28, \mathrm{~s}$ & 11.7 & C-2 \\
\hline $5-\mathrm{OCH}_{3}$ & $3.84, \mathrm{~s}$ & 56.0 & C-5 \\
\hline $9-\mathrm{OCH}_{3}$ & $3.65, \mathrm{~s}$ & 52.0 & C-9 \\
\hline
\end{tabular}


Table $3{ }^{1} \mathrm{H}(600 \mathrm{MHz})$ and ${ }^{13} \mathrm{C}(151 \mathrm{MHz}) \mathrm{NMR}$ data for compound 6 in $\mathrm{CDCl}_{3}$.

\begin{tabular}{|c|c|c|c|}
\hline Position & $\left.\delta_{\mathrm{H} \square \mathrm{m}}\right] J$ in $\mathrm{Hz} \square$ & $\delta_{\mathrm{C}}$ & HMBC \\
\hline 1 & $7.12, \mathrm{~s}$ & 104.3 & $\mathrm{C}-2, \mathrm{C}-12 \mathrm{a}, \mathrm{C}-12$ \\
\hline 2 & & 148.0 & \\
\hline 3 & & 147.5 & \\
\hline 4 & $7.57, \mathrm{~s}$ & 101.0 & $C-3, C-4 b$ \\
\hline $4 a$ & & 131.1 & \\
\hline $4 b$ & & 139.3 & \\
\hline 6 & $5.02, \mathrm{~m}$ & 55.1 & $C-4 b, C-10 a$ \\
\hline $6 a$ & & 128.0 & \\
\hline 7 & & 145.5 & \\
\hline 8 & & 152.1 & \\
\hline 9 & $6.99, \mathrm{~d}(J=8.5 \mathrm{~Hz})$ & 111.6 & C-7, C-10a \\
\hline 10 & $7.58, \mathrm{~d}(J=8.5 \mathrm{~Hz})$ & 118.8 & C-8, C-10b, C-6a \\
\hline $10 a$ & & 124.9 & \\
\hline $10 \mathrm{~b}$ & & 123.8 & \\
\hline 11 & $7.73, \mathrm{~d}(J=8.7 \mathrm{~Hz})$ & 119.8 & $C-4 b, C-4 a, C-10 a$ \\
\hline 12 & $7.50, \mathrm{~d}(J=8.7 \mathrm{~Hz})$ & 124.0 & $C-1, C-10 b, C-12 a$ \\
\hline $\begin{array}{c}12 \mathrm{a} \\
\mathrm{N}-\mathrm{CH}_{3}\end{array}$ & $2.68, \mathrm{~s}$ & $\begin{array}{c}127.5 \\
42.9\end{array}$ & C-6 \\
\hline $7-\mathrm{OCH}_{3}$ & 3.99, s & 61.0 & $\mathrm{C}-7$ \\
\hline $8-\mathrm{OCH}_{3}$ & $3.95, \mathrm{~s}$ & 55.8 & C-8 \\
\hline$-\mathrm{O}-\mathrm{CH}_{2}-\mathrm{O}-$ & $6.06, \mathrm{~s}$ & 101.0 & \\
\hline $1^{\prime}$ & & 171.7 & \\
\hline $2^{\prime}$ & $2.38, \mathrm{~s}$ & 39.2 & $C-1^{\prime}, C-6$ \\
\hline $3^{\prime}$ & $4.17, \mathrm{~d}(J=7.1 \mathrm{~Hz})$ & 60.3 & \\
\hline $4^{\prime}$ & $1.21, \mathrm{~d}(J=7.1 \mathrm{~Hz})$ & 14.2 & $C-3^{\prime}$ \\
\hline
\end{tabular}

Table $4{ }^{1} \mathrm{H}(600 \mathrm{MHz})$ and ${ }^{13} \mathrm{C}(151 \mathrm{MHz})$ NMR data for compound 16 in Pyridine- $d_{5}$.

\begin{tabular}{|c|c|c|c|}
\hline Position & $\delta_{\mathrm{H}} \mathrm{m} \square J$ in $\mathrm{Hz} \square$ & $\delta_{\mathrm{C}}$ & HMBC \\
\hline 2 & & 164.5 & \\
\hline 3 & & 101.6 & \\
\hline 4 & & 142.3 & \\
\hline $4 a$ & & 114.1 & \\
\hline 5 & $8.13, \mathrm{~d}(9.1)$ & 118.8 & $\mathrm{C}-4, \mathrm{C}-8, \mathrm{C}-8 \mathrm{a}$ \\
\hline 6 & $7.54, \mathrm{~d}(9.1)$ & 117.3 & $C-7, C-8, C-4 a$ \\
\hline 7 & & 140.2 & \\
\hline 8 & & 151.6 & \\
\hline $8 a$ & & 157.4 & \\
\hline $3 b$ & $7.15, d(2.7)$ & 105.3 & C- $2, C-3, C-4$ \\
\hline $2 a$ & $7.80, \mathrm{~d}(2.7)$ & 142.9 & $C-2, C-3, C-3 b$ \\
\hline 7- $\mathrm{OCH}_{3}$ & $4.23, \mathrm{~s}$ & 61.1 & C-7 \\
\hline $8-\mathrm{OCH}_{3}$ & $4.27, \mathrm{~s}$ & 58.9 & C-8 \\
\hline$-\mathrm{OH}$ & $12.03, \mathrm{~s}$ & & \\
\hline
\end{tabular}


Table 5 Inhibitory activity of compounds 1-26 in HEL cell lines.

\begin{tabular}{cccc}
\hline Compounds & $\mathrm{IC}_{50}(\mu \mathrm{M}) \pm \mathrm{SD}$ & Compounds & $\mathrm{IC}_{50}(\mu \mathrm{M}) \pm \mathrm{SD}$ \\
\hline $\mathbf{1}$ & $28.84 \pm 1.53$ & 14 & $3.59 \pm 0.82$ \\
2 & $22.43 \pm 1.86$ & 15 & $15.52 \pm 0.26$ \\
$\mathbf{3}$ & $>30$ & 16 & $>30$ \\
$\mathbf{4}$ & $>30$ & 17 & $>30$ \\
5 & $>30$ & 18 & $>30$ \\
6 & $>30$ & 19 & $>30$ \\
7 & $>30$ & 20 & $>30$ \\
$\mathbf{8}$ & $>30$ & 21 & $>30$ \\
9 & $7.65 \pm 0.11$ & 22 & $>30$ \\
10 & $24.94 \pm 1.99$ & 23 & $>30$ \\
11 & $>30$ & 24 & $15.95 \pm 2.33$ \\
12 & $>30$ & 25 & $>30$ \\
13 & $>30$ & 26 & $>30$ \\
DOX & $0.021 \pm 1.25$ & & \\
\hline
\end{tabular}

\section{Figures}
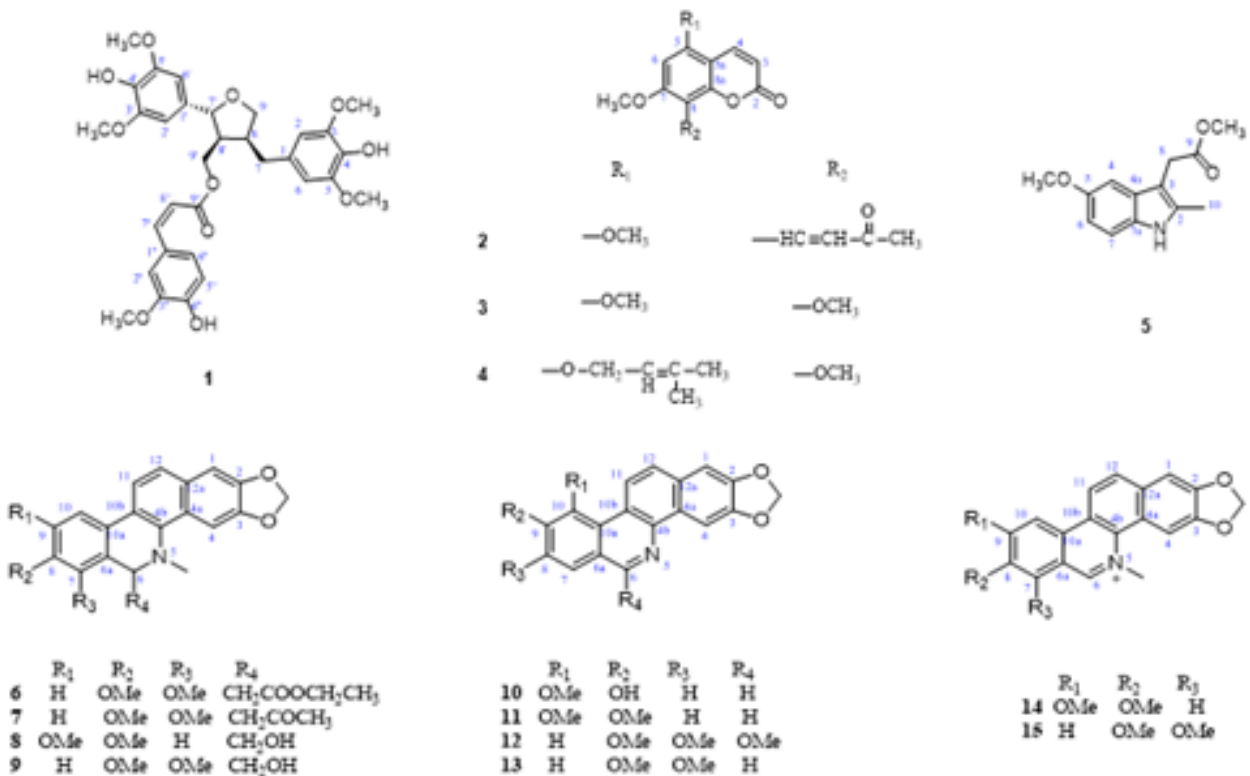

14 ONe

$\begin{array}{llll}12 & \mathrm{H} & \text { OMSe OMe ONe } \\ 13 & \mathrm{H} & \text { OMSe OMS } & \mathrm{H}\end{array}$
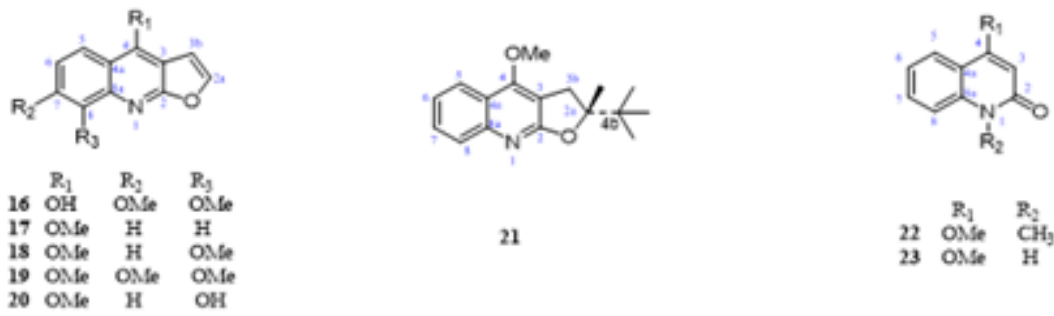

21
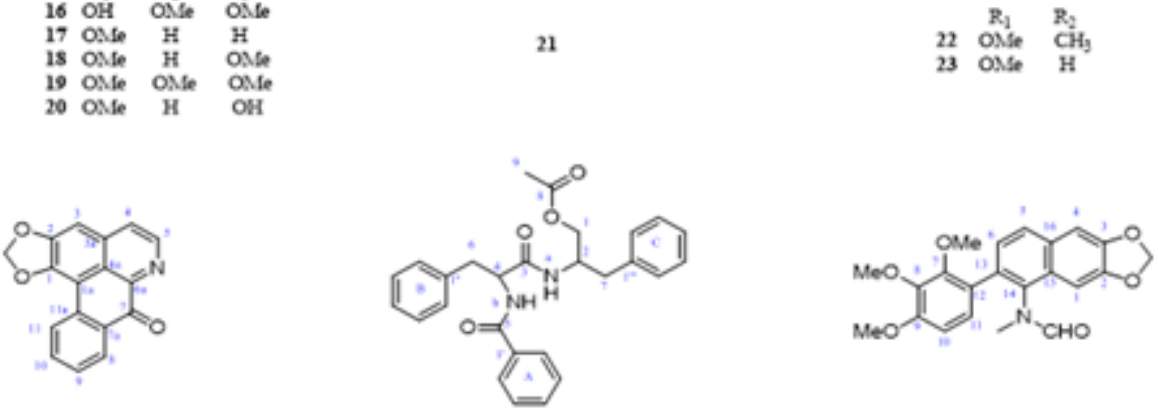

24

25

26 
Figure 1

Compounds 1-26 isolated from the roots and leaves Zanthoxylum nitidium


$10 \begin{array}{llll}R_{1} & R_{4} & R_{3} & R_{4} \\ \text { OMe } & \text { OH } & H & H\end{array}$

11 OMe OMe H H

12 H OMS ONe OMe

13 H ONS OMS $\mathrm{H}$
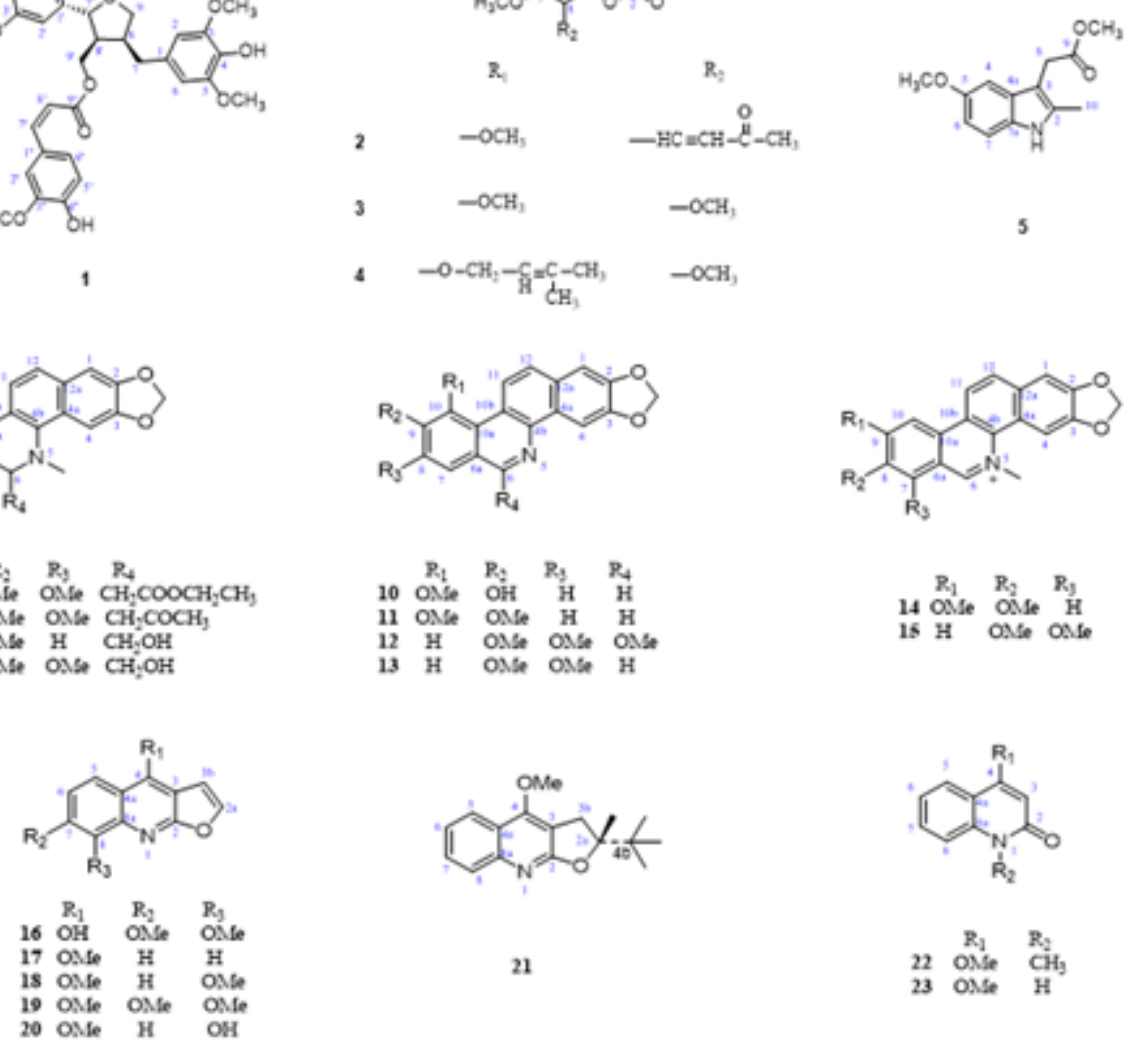

21

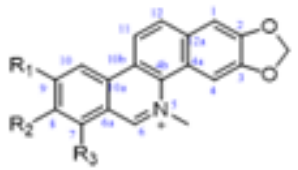

20 OMe $\mathrm{H}$ OH

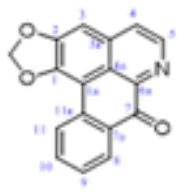

24

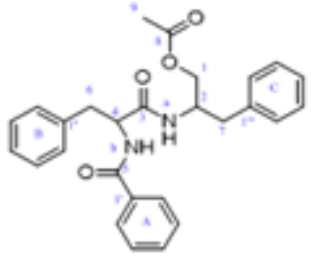

25

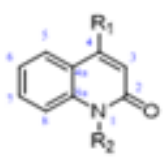

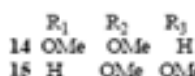

$\begin{array}{lll}22 & \mathrm{R}_{1} & \mathrm{R}_{2} \\ 23 & \text { ONse } & \stackrel{\mathrm{H}}{\mathrm{CH}}\end{array}$

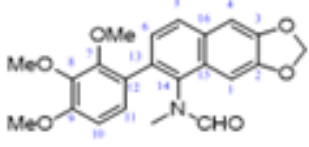

26

\section{Figure 1}

Compounds 1-26 isolated from the roots and leaves Zanthoxylum nitidium 


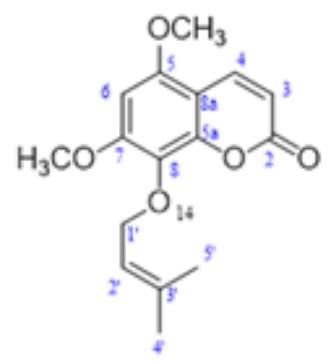

8-(3', 3'-dimethyl-2'-butenyloxy)-5, 7-methoxy-coumarin (4')

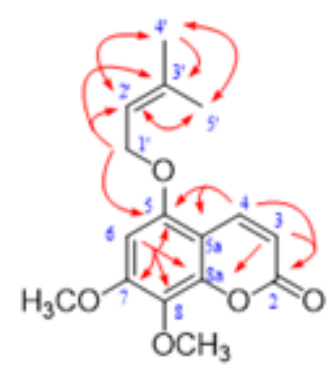

compound 4

\section{Figure 2}

The structure of compound $4 \rrbracket$ and HMBC correlations of compound 4

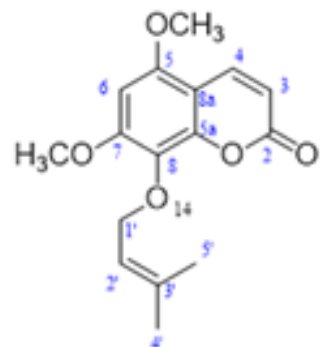

8-(3', 3'-dimethyl-2'-butenyloxy)-5, 7-methoxy-coumarin (4')

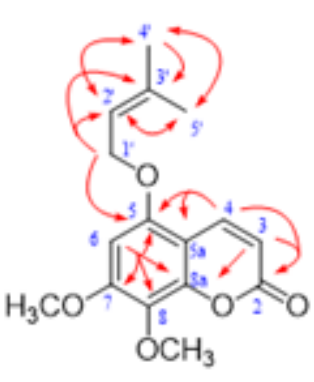

compound 4

\section{Figure 2}

The structure of compound $4 \rrbracket$ and HMBC correlations of compound 4 


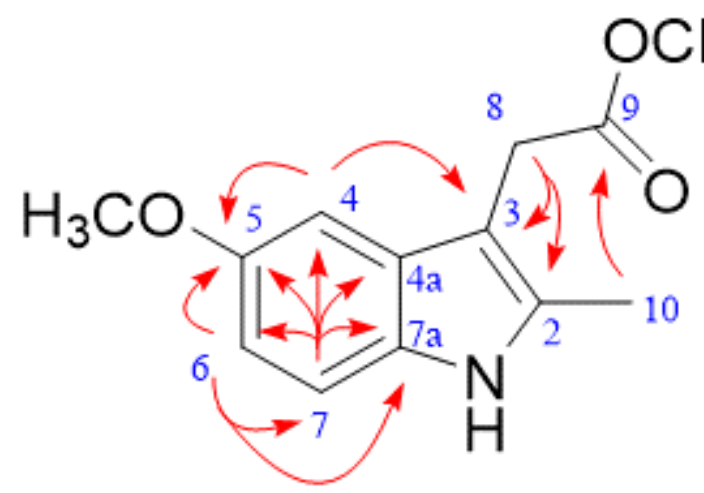

Figure 3

HMBC correlations of compound 5

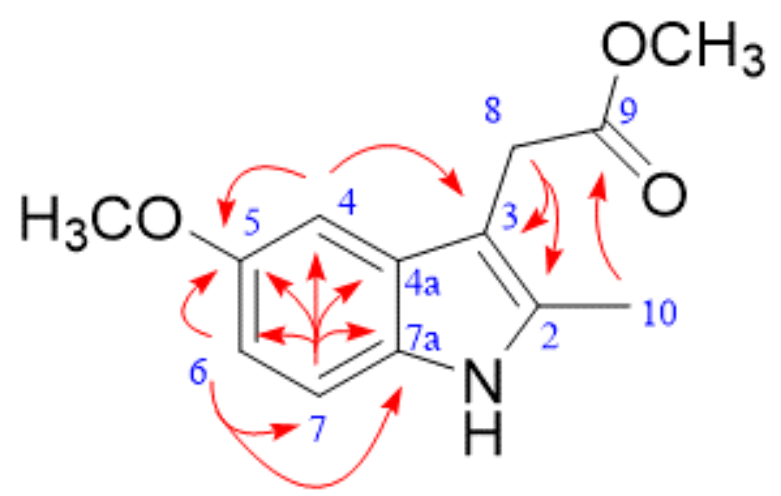

Figure 3

HMBC correlations of compound 5

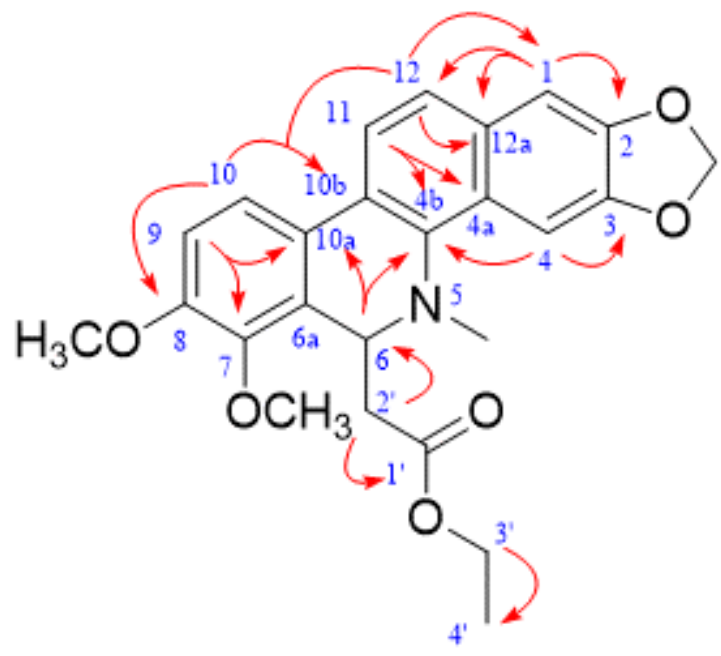

Figure 4 
HMBC correlations of compound 6.

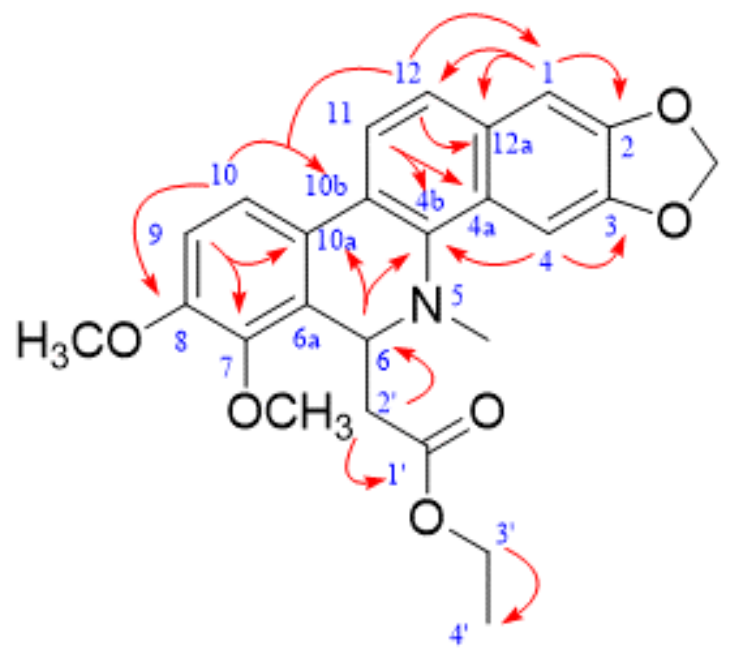

Figure 4

HMBC correlations of compound 6.

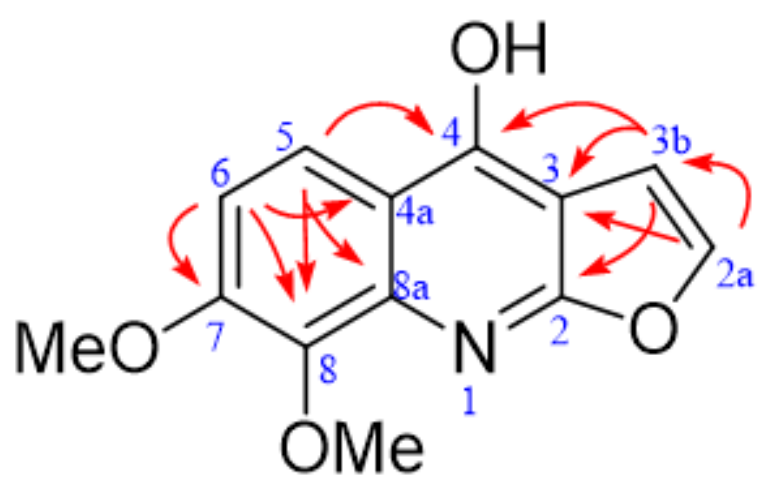

Figure 5

HMBC correlations of compound 16

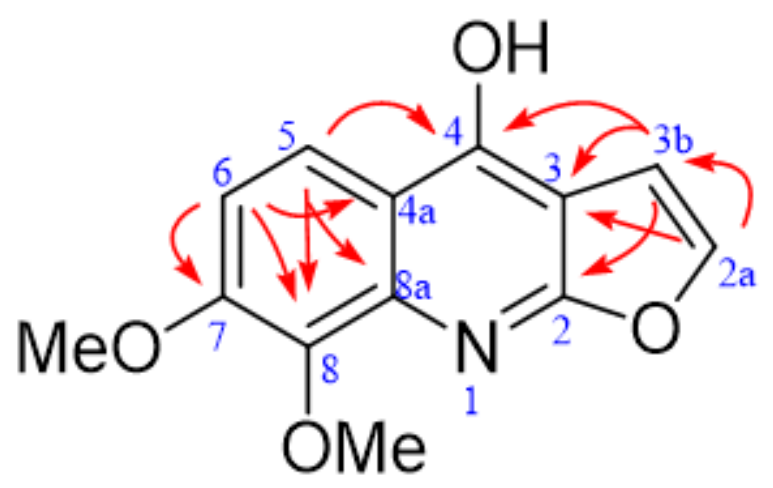


Figure 5

HMBC correlations of compound 16
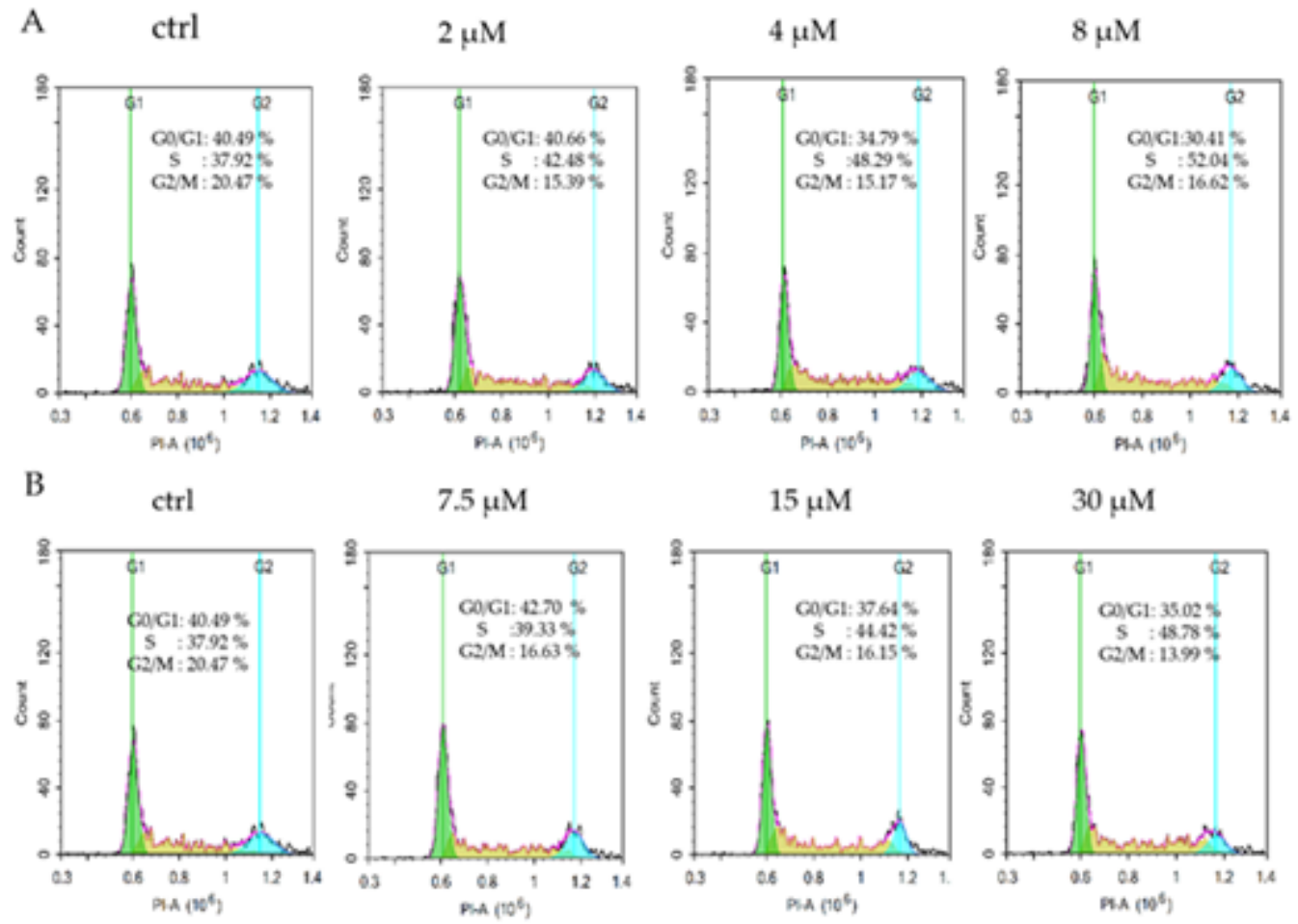

Figure 6

(A) Compound 14 induced cell cycle arrest at the phase. Compound 14 altered cell cycle distribution in HEL cells. Cells were exposed to DMSO or compound 14 at indicated concentrations for $36 \mathrm{~h}$ and then were collected for DNA content analysis by flow cytometric analysis as experiment. (B) Compound 24 induced cell cycle arrest at the phase. Compound 24 altered cell cycle distribution in HEL cells. Cells were exposed to DMSO or compound 24 at indicated concentrations for $36 \mathrm{~h}$ and then were collected for DNA content analysis by flow cytometric analysis as experiment. 

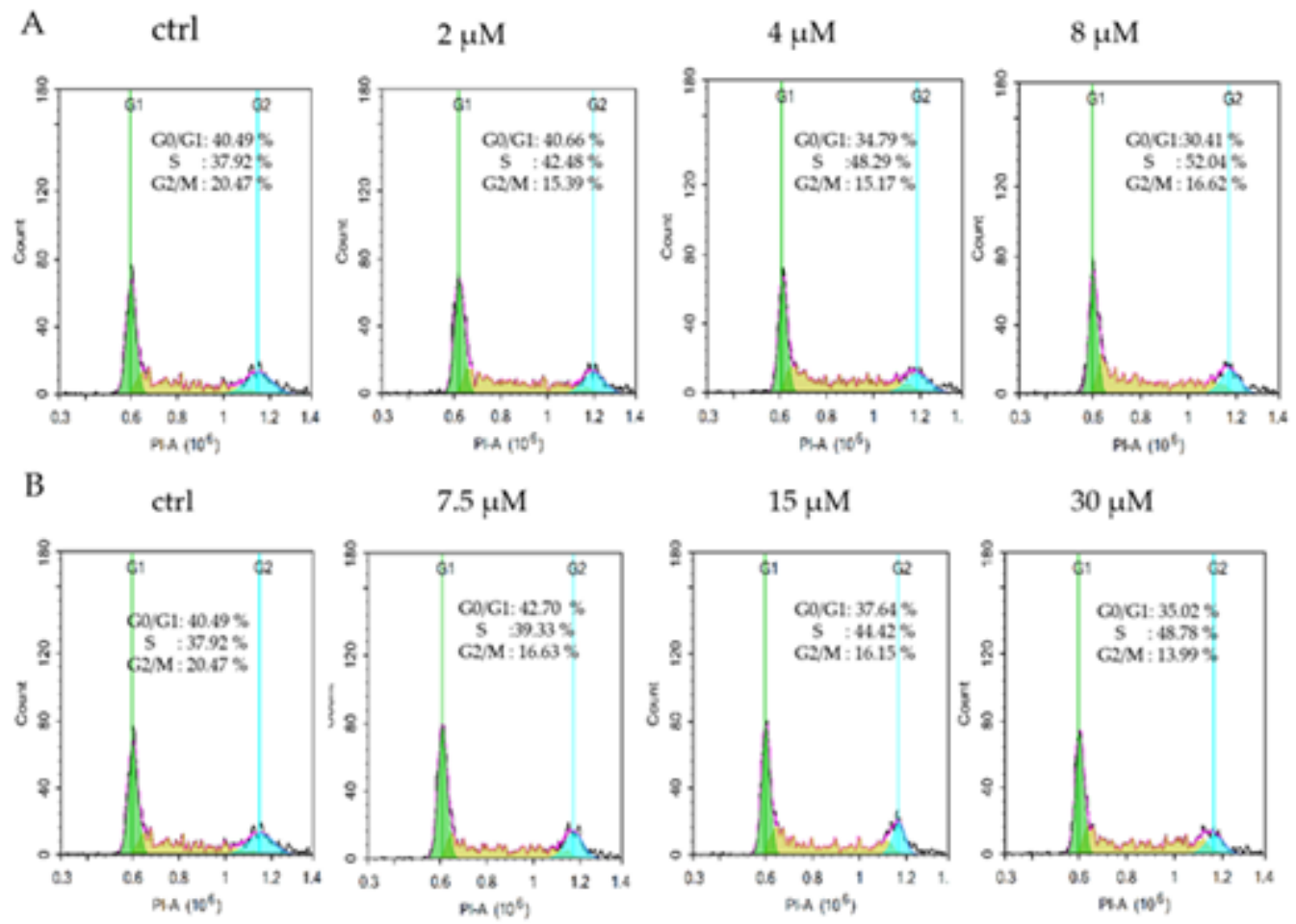

\section{Figure 6}

(A) Compound 14 induced cell cycle arrest at the phase. Compound 14 altered cell cycle distribution in HEL cells. Cells were exposed to DMSO or compound 14 at indicated concentrations for $36 \mathrm{~h}$ and then were collected for DNA content analysis by flow cytometric analysis as experiment. (B) Compound 24 induced cell cycle arrest at the phase. Compound 24 altered cell cycle distribution in HEL cells. Cells were exposed to DMSO or compound 24 at indicated concentrations for $36 \mathrm{~h}$ and then were collected for DNA content analysis by flow cytometric analysis as experiment. 



Figure 7

(A) Compound 14 induced apoptosis in HEL cells. Cell apoptosis was analyzed by flow cytometric analysis after Annexin V-FITC/PI staining. Cells were collected and centrifuged at $1500 \mathrm{rpm}$ for $10 \mathrm{~min}$ after compound 14 treatment at the indicated concentrations for $36 \mathrm{~h}$. (B) Compound 24 induced apoptosis in HEL cells. Cell apoptosis was analyzed by flow cytometric analysis after Annexin V-FITC/PI staining. Cells were collected and centrifuged at $1500 \mathrm{rpm}$ for $10 \mathrm{~min}$ after compound 24 treatment at the indicated concentrations for $36 \mathrm{~h}$. The changes in corresponding protein expression levels were quantified using Image $J$. Each bar represents the mean \pm SEM $(n=3) . P<0.05$, ${ }^{\star *} P<0.01$ or ${ }^{\star \star \star} P<$ 0.001 was considered statistically significant compared with the corresponding control values. 

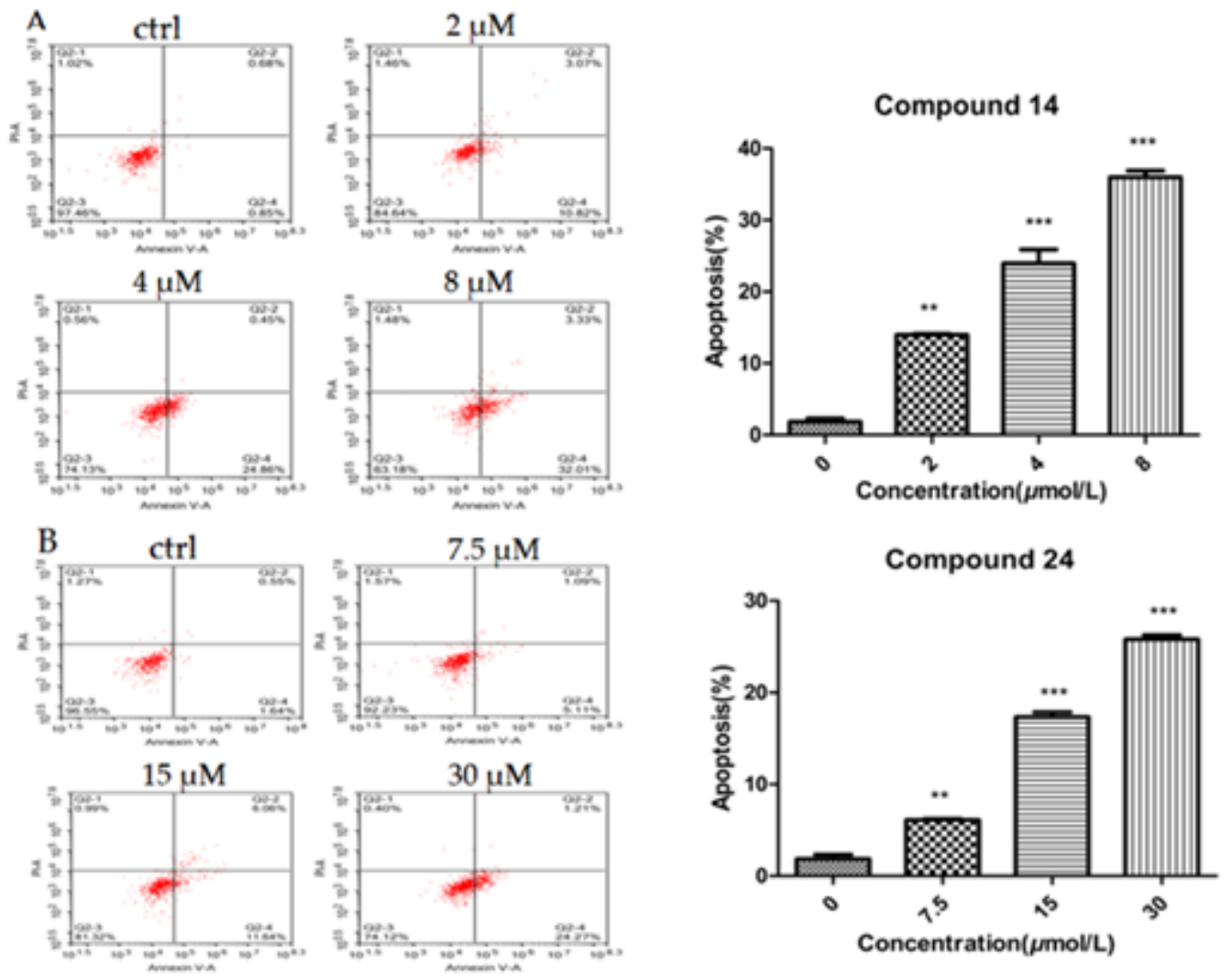

Figure 7

(A) Compound 14 induced apoptosis in HEL cells. Cell apoptosis was analyzed by flow cytometric analysis after Annexin V-FITC/PI staining. Cells were collected and centrifuged at $1500 \mathrm{rpm}$ for $10 \mathrm{~min}$ after compound 14 treatment at the indicated concentrations for $36 \mathrm{~h}$. (B) Compound 24 induced apoptosis in HEL cells. Cell apoptosis was analyzed by flow cytometric analysis after Annexin V-FITC/PI staining. Cells were collected and centrifuged at $1500 \mathrm{rpm}$ for $10 \mathrm{~min}$ after compound 24 treatment at the indicated concentrations for $36 \mathrm{~h}$. The changes in corresponding protein expression levels were quantified using Image $J$. Each bar represents the mean \pm SEM $(n=3) . P<0.05$, ${ }^{\star *} P<0.01$ or ${ }^{\star \star \star} P<$ 0.001 was considered statistically significant compared with the corresponding control values.

\section{Supplementary Files}

This is a list of supplementary files associated with this preprint. Click to download.

- Supplementaryrevised116.docx

- Supplementaryrevised116.docx 